\title{
Distribution and Dynamics of a Tropical Waterfalls Ecosystem
}

\author{
Benedict Obeten Offem ${ }^{1, *}$, Gabriel Ujong Ikpi \\ ${ }^{1}$ Department of Fisheries and Aquatic Science, Faculty of Agriculture and Forestry, Cross River University \\ ${ }^{2}$ Technology, Nigeria, Obubra campus, Obubra, Cross River State, Nigeria
}

\begin{abstract}
Waterfalls gives the impression of a lifeless zone because researchers have historically focused on the hydrology, ecotourism and geological features. Effective management will require an understanding of changes in species composition and distribution of macro-biota. Monthly samples were taken in wet and dry seasons, over two year period in three regions along the $6817.7 \mathrm{~m}$ length of the Agbokum waterfalls. Macro-biota exhibited distinct pattern in respect of seasonal and spatial changes. Trachelomonas volzii, the most abundant phytoplankton species reduced from 686 in the dry season to 143 in the wet, and from 455 downstream to 91, midstream (waterfalls region). Zooplankton species Calanus finmarchicus decreased from 511 during dry season to 36 in the wet and from 334 downstream to 7 , midstream. 71.7 percent of the total macro-invertebrates were recorded from downstream reaches while only 6.3 percent were contributed by midstream. Among the three dominant fish species Tilapia zillii, Clarias gariepinus and Labeo coubie, constituting $45.5 \%$ of total catch, two benthic fishes (L. coubie and C. gariepinus) showed inverse distributional patterns. Clariid fish (C. gariepinus) was most abundant downstream and least represented upstream. Cyprinid (L.coubie), on the other hand, dominated the upstream reaches and scarce downstream. Percentage cover of marginal vegetation by Bambusasp, Symphonia and Elaeis guineesis displayed progressive increase from upstream reaching a maximum of 38.5 mean percent cover in the relatively undisturbed downstream. In contrast, Raphia vinifera, Havea brasiliensis, Grewia sp and Cocos nucifera shrank in size from $34 \%$ to $8 \%$ at the midstream stretches of the river while only nymphia- rich vegetation becomes more frequent in the middle reaches. Nymphia has become a biological invader and has exhibited a full range of impact and abundance in this disturbed midstream reaches. The disturbance regimes of the midstream reaches of Agbokum waterfalls combined with its very low faunal and floral diversity has made the environment unstable therefore susceptible to the invasion of disturbance tolerant biota.
\end{abstract}

Keywords Waterfalls, Macro-Invertebrates, Phytoplankton, Zooplankton, Vegetation, Fish Species, Physic-Chemical Properties

\section{Introduction}

Waterfalls, most of which are formed from stream or river which cascade from a high elevation over a cliff or rock, had very little attention from researchers the world over. In Africa, the reason being that, waterfalls were named after deities and were used as places of traditional and ancestral worships. In other places, the intensity of waterfalls andpressure generated from it due to gravity has given the im- pression of a lifeless zone[1]. Knowledge of waterfalls systems in Africa are therefore limited to hydrology and geological features[2,3], as natural monuments for revenue generation, because of their ecotourism potentials[4] and as source for drinking, irrigation and other domestic purposes. Studies on the fisheries and aquaculture

* Corresponding author:

benbeff06@yahoo.com (Benedict Obeten Offem)

Published online at http://journal.sapub.org/ije

Copyright (C) 2012 Scientific \& Academic Publishing. All Rights Reserved potentials, biodiversity conservation and aquatic ecology of waterfalls are scarce.

Knowledge of status of the fauna and flora of Agbokum waterfall is important in the development and management of conservation measures. It is also possible that the biodiversity of Cross river fishes is much higher than reported[5, 6] and could yield records of undiscovered and un-described species if the Agbokim Waterfalls and other water bodies such as Crater lakes, flood plains, lakes and mountain streams which link up with the Cross River, are investigated. The fundamental attributes of an aquatic ecosystem are the number of species present and their abundance[7]. Both attribute are dynamic and related[8]. In aquatic ecosystems interaction between the environment and population processes affects the distribution and abundance patterns of species[9,10]. The resources of the length of the waterfalls are yet to be tapped, more so due to the total neglect by stakeholders. This study presents an analysis of the occurrence, distribution and dynamics in the fauna and flora resources of Agbokim waterfalls to reduce our over- dependence on es- 
tuarine and open water body systems.

\section{Methods}

\subsection{Study Area}

The study area is Agbokim Waterfalls in Cross River State, Nigeria, latitude $5^{\circ} 59^{\prime}$ North and longitude $8^{\circ} 45^{\prime}$ East. It is bounded in the West by the Cross River and in the North by the Cameroon high forests. The climate is the tropical hinter-land type, with wet (May-November) and dry (December-April) seasons. Mean annual temperature ranged between $20^{\circ} \mathrm{C}$ and $32^{\circ} \mathrm{C}$ and annual total average rainfall, from $1450 \mathrm{~mm}$ to $3015 \mathrm{~mm}$. The vegetation is the rainforest type with Soil consisting of deep laterite and dark fertile, clayey and loamy soils. The Agbokim waterfall as most others is a product of two rivers, River Ekim and River Bakue, which are tributaries of the Cross River system. River Ekim is divided into three streams, while River Bakue has four streams. These seven streams flow into a floodplain, from where they independently cascade over steep cliff which provides seven-faced falls into the casket or waterfalls. Of ecological importance are numerous small pools and swamps which are found along the length of the waterfalls. The high annual discharge and rainfall of the area provide excellent buffers against natural ecological stresses such as drought[9]. For the purpose of this study, the $6817.7 \mathrm{~m}$ long waterfall is divided into three reaches; upstream, midstream (region of waterfalls) and downstream. Upstream is 2003.13 $\mathrm{m}$ long with substrate of gravel and rocks under fast water current and shoreline covered with high forest and cocoa farms, Midstream length of $807.42 \mathrm{~m}$ has substrates of sand and rocks under heavy water turbulence with shoreline sparsely shaded with vegetation while downstream length, $4007.15 \mathrm{~m}$ has fine sand and clay under slow water current with an extensive wide area.

\subsection{Plankton Studies}

Phytoplankton samples were collected monthly, from August 2005 - July 2007. These were collected in $250 \mathrm{ml}$ bottles[11]. The water samples, for plankton analysis was taken to the Fisheries Laboratory of Cross River University of Technology, Obubra Campus, Cross River State. Fresh sample was mixed gently and pipetted into $5 \mathrm{ml}$ plankton chamber containing 2 drops of Lugol's solution. The Lugol's solution served as the fixative while also enhancing sedimentation of organisms. The chamber was left overnight for complete sedimentation to take place. Plankton was analyzed using Zeiss inverted plankton microscope[12] using Plankton determination keys[13-15].

Zooplankton was sampled from a scoop plastic bucket of 10 liter capacity. Subsurface water ( $5 \mathrm{~m}$ depth) was vertically collected with a bucket and filtered through plankton net of mesh size $100 \mu$. Fifty scoop buckets of 10 liter capacity were filtered via the net. The net samples were washed into the 1 $\mathrm{ml}$ sample collecting bottles and fixed immediately in $2 \%$ formalin solution. After making up to $100 \mathrm{ml}$ with distilled water, the samples were agitated and homogenized and $1 \mathrm{ml}$ sub-samples placed in counting chamber for observation under 40-100 $\times$ magnification. Organisms were identified[16,17] and enumerated for subsequent statistical computations.

\subsection{Faunal Studies}

Macro-invertebrate benthic fauna samples of the waterfalls were collected four times near the margin of the river at each reach by use of a corer $0.004 \mathrm{~m}^{2}$ already described[18] and modified[19]. Three replicate samples were taken from each reach and transferred to separately labeled polythene bags for laboratory analysis. Sieves with meshsizes $2 \mathrm{~mm}$ and $1 \mathrm{~mm}$ were used to screen the organisms that were later sorted and preserved in $5 \%$ buffered formalin. The individual organisms were identified using a stereoscopic microscope and identification guides[21-23]

The fish of the river was sampled in all the reaches using gill net (22-76mm stretched mesh size). Genus and species identifications was carried out for the Cyprinids[24], for the Bagrids[25]; for the Clariidae[26] and for the Clupeidae and Mugilidae[27]. Fish catch of each reach was presented as a numerical contribution by each species. This was determined by calculating the ratio each species, represented of the total catch for each reach based on the number of species and relative abundance.

\subsection{Environmental Parameters}

Water level was determined with a lead sinker attached to a calibrated rope. The sinker was lowered down into water until it reached the substrate. The depth was then read from the calibrated rope. The procedure was repeated in two other locations randomly selected from the edge and middle of water within the sampling site. River width was measured with a long calibrated rope in three places in each sampling sites and the average was taken. Water velocity (flow velocity) was determined to $0.03 \mathrm{~m} / \mathrm{sec}$ accuracy with Wagtech current flow meter, model WFM001 with $125 \mathrm{~mm}$ diameter impella. Water discharge was determined[28] using the formula: WTD $=$ CSA $\times$ WD $\times$ WV. Where WTD $=$ Water discharge $\left(\mathrm{m}^{3} \mathrm{~s}^{-1}\right), \mathrm{CSA}=$ Cross Sectional Area $(\mathrm{m})$; WD $=$ Water dept $(\mathrm{m})$ and $\mathrm{WV}=$ Water velocity $\mathrm{ms}^{-1}$. Temperature values were recorded from a mercury-in glass thermometer graduated in units of ${ }^{\circ} \mathrm{C}\left(50^{\circ} \mathrm{C}\right)$ by immersing the thermometer slightly under the surface of water $(2 \mathrm{~cm})$ for 5 minutes until mercury stood at one place). PyeUnicam Model 7065 electronic metre at $25^{\circ} \mathrm{C}$ after standardization with buffer solution at $\mathrm{pH} \mathrm{4,7}$ and 9 was used for $\mathrm{pH}$. The dissolved oxygen concentration of the water samples was determined with a Fischers digital oxygen analyzer.

\subsection{Vegetation}

Studies of the vegetation was carried out by selecting three populations from the three reaches to represent different degrees of disturbances. All populations were vigorous and 
healthy in all sampling sites, when the study began in 2007 . In each reach, random stations, $20 \times 20$ in each were mapped out and labeled markers placed within each quadrat and mapped with the plants. At intervals of 4-6 months, all plants, within a quadrat, were mapped and the following figures recorded for each seedling or established shoot status number damaged, presence or absence of individuals and their zonation patterns were also noted.

\subsection{Data Treatment and Analysis}

The mean and standard deviation of each of the physico-chemical parameters were calculated. Analysis of variance (ANOVA) was used to test for statistical differences between the means of the physical and chemical parameters of the sampling sites. To calculate mean abundance, numbers in different samples were summed for each species and averaged across all sampling sites. Physico-chemical parameters were correlated with the abundances of fish species using Pearson product moment correlation coefficient analysis. Shannon-Wiener diversity function $(\mathrm{H})$ was used to calculate heterogeneity for each site. Richness index was expressed using Margalef's richness index.

$$
\begin{gathered}
\mathrm{d}=(\mathrm{S}-1) / \log \mathrm{N}[29] \\
H^{\prime}=-\sum_{i=1}^{S} P_{i} \operatorname{LnPi}[30]
\end{gathered}
$$

$\mathrm{E}=\mathrm{d} / \mathrm{S}[31]$

$\mathrm{E}=$ Equitability

$\mathrm{d}=$ Margalef's richness index and $\mathrm{H}^{\prime}=$ Shannon-Wiener

Diversity Function

$\mathrm{S}=$ total species number

$\mathrm{p}_{\mathrm{i}}=$ proportion of each species in each sample

Relative abundance $\%=(\mathrm{n} / \mathrm{N}) \times 100$,

$\mathrm{n}$ refers to the number of individuals of the species in the samples and $\mathrm{N}$ to the total number of individuals of fish caught.

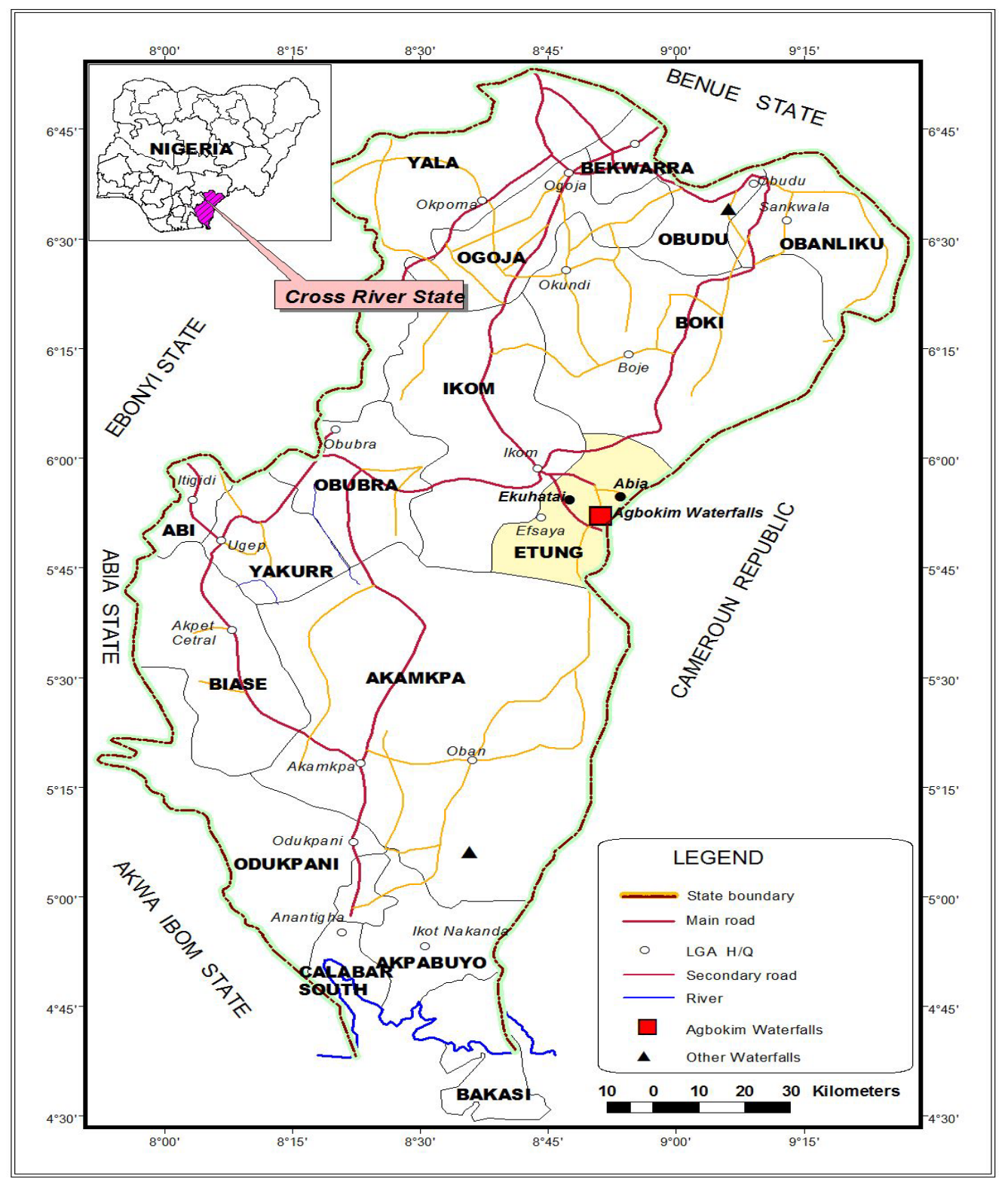

Figure 1. Map of Cross River State showing Agbokim Waterfalls 


\section{Results}

\subsection{Plankton}

Table 1. Plankton spatial numerical composition and diversity of Agbokim Waterfalls in wet (W) and dry (D) season for the three sites, upstream, midstream and downstream for 2005-2007

\begin{tabular}{|c|c|c|c|c|c|c|}
\hline \multirow{2}{*}{$\begin{array}{l}\text { Reaches } \\
\text { Seasons }\end{array}$} & \multicolumn{2}{|c|}{ Upstream } & \multicolumn{2}{|c|}{ Midstream } & \multicolumn{2}{|c|}{ Downstream } \\
\hline & $\mathrm{D}$ & W & $\mathrm{D}$ & $\mathrm{W}$ & $\mathrm{D}$ & $\mathrm{W}$ \\
\hline \multicolumn{7}{|l|}{ Plankton taxa/species } \\
\hline \multicolumn{7}{|l|}{ Phytoplankton } \\
\hline \multicolumn{7}{|l|}{ Chlorophyceae } \\
\hline Akinstrodesmus spiralis & 46 & - & 57 & 4 & 32 & 16 \\
\hline Phacus quinquemarginatus & 20 & 18 & 32 & 5 & 13 & 10 \\
\hline Trachelomonas volvocina & 91 & 55 & 69 & 22 & 318 & 17 \\
\hline Trachelomonas volzii & 163 & 123 & 91 & & 432 & 23 \\
\hline Euglena acus & 14 & 3 & 26 & 3 & 2 & 1 \\
\hline Astasia klebsii & 8 & 2 & 13 & 3 & 3 & 4 \\
\hline Euglenopsis vorax & 5 & 5 & 7 & 5 & 1 & \\
\hline Spirogyra varians & 9 & & 7 & 3 & 11 & \\
\hline Selenastrum gracile & 25 & 5 & 13 & & 88 & 13 \\
\hline Scenedesmus denticulatus & 46 & 20 & 44 & 31 & 3 & 6 \\
\hline Zygenma insigne & 5 & & 7 & 4 & 55 & \\
\hline Dictyosphaerium pulchellum & 4 & & 4 & & 14 & 8 \\
\hline Tribonema bombycinum & 2 & & 87 & 13 & 2 & 22 \\
\hline Mougeotia transeaui & 2 & & 6 & 3 & & 21 \\
\hline Volvox tertius & 7 & & 11 & 12 & & 8 \\
\hline Ulothrix cylindricum & 2 & & 4 & 3 & & 3 \\
\hline Eudorina elegans & 1 & & 2 & 5 & & 7 \\
\hline Chlamydomonas ehrenbergii & 2 & 8 & 4 & 2 & 1 & 22 \\
\hline Chlorella ellipsoidea & 112 & 18 & 38 & 12 & 212 & 44 \\
\hline \multicolumn{7}{|l|}{ Cyanophyceae } \\
\hline Anabaena bornetiana & 11 & & 15 & 19 & 27 & \\
\hline Aphanizomeno holsaticum & 22 & & 15 & 11 & 32 & \\
\hline Nostochopsis lobatus & 12 & 3 & 19 & 2 & & 5 \\
\hline Nostoc lobatus & & & 49 & 10 & 43 & 8 \\
\hline Bacillariophyceae & & 13 & & & & \\
\hline Navicula radiosa & 21 & 12 & 12 & & 27 & \\
\hline Nitzschia sigmoidea & 34 & 12 & 12 & 21 & 88 & 19 \\
\hline Synedra ulna & 54 & 16 & 12 & 4 & 76 & 10 \\
\hline Chaetoceros elmorei & & 4 & & 4 & 37 & 8 \\
\hline Cryptophyceae & 23 & 1 & 8 & & & 15 \\
\hline Cryptomonas erosa & & 9 & 11 & 14 & & 3 \\
\hline \multicolumn{7}{|l|}{ Dinophyceae } \\
\hline Gymnodinium palustre & & 13 & 4 & 10 & 5 & \\
\hline \multicolumn{7}{|l|}{ Zooplankton } \\
\hline \multicolumn{7}{|l|}{ Rotifera } \\
\hline Filinia longiseta & 4 & & & 2 & 12 & 16 \\
\hline Lecane bulla & 12 & & 3 & 2 & 6 & 27 \\
\hline Synchaeta oblonga & 3 & 1 & 3 & 1 & 13 & 11 \\
\hline Bracchionus quadridentatus & 4 & 6 & 4 & 2 & 19 & 94 \\
\hline Cladocera & & 138 & & & & \\
\hline Moina micrura & 1 & & & & 51 & 151 \\
\hline Bosmina longirostris & 14 & - & 8 & 2 & 34 & \\
\hline Daphnia magna & 1 & 3 & 4 & 2 & 17 & 25 \\
\hline Diaphanosoma excisum & & & & 1 & & 21 \\
\hline \multicolumn{7}{|l|}{ Copepoda } \\
\hline Calanus finmarchicus & 211 & 35 & 6 & 1 & 344 & \\
\hline Pseudocalanus elongate & 4 & 2 & 3 & 1 & 115 & 28 \\
\hline Acartia tonsa & 22 & 1 & 1 & 4 & 7 & 91 \\
\hline Tisbe holothuriae & 4 & & 8 & 1 & 35 & 8 \\
\hline Schizopera elatensis & 8 & 4 & 2 & 1 & 30 & 23 \\
\hline
\end{tabular}

A total of 29 phytoplankton species sampled from five taxonomic groups; Chlorophyceae, Cyanophyceae, Bacillariophyceae, Cryptophyceae and Dinophyceae, represented phytoplankton community of the Agbokum waterfalls (Table 1). Chlorophyceae was the dominant group and Trachelo- monas volzii most abundant species within the group. The dry season samples recorded higher values (718) of individual Trachelomonas volzii than the wet. Three major taxonomic forms of zooplankton; rotifer, cladocera and copepod, consisting of 13 species were recorded. Copepoda (51) was dominant zooplankton with Calanus finmarchicus as most abundant species in the dry season while dominant wet season zooplankton Moina micrura (256) represent 65\% of total zooplankton. About $78.6 \%$ of total phytoplankton and zooplankton was contributed from downstream populations while only $10 \%$ from midstream.

\subsection{Macro-faunal Composition and Distribution}

Macro-invetebrates assemblages collected from the waterfalls consist of nine major taxa and 1878 individuals (Figure 2). Spatial distribution of the taxa and individuals recorded upstream, midstream and downstream reaches were 9 (413), 9 (113) and 9 (1346) respectively. Dipterans and nematodes were dominant groups representing 15.4 and 15.2 percent respectively; decapods and annelids represent 14.7 and 13.5 percent respectively. Coleoptera was the least group (6.5\%). About 71.7 percent of the total macro- invertebrates were recorded from downstream reaches while only 6.3 percent were contributed by midstream. Seasonal variation of the invertebrates in the different reaches showed that the dry season samples were significantly higher (1416) (p $<0.05$ ) than the wet (462) (Figure 3).

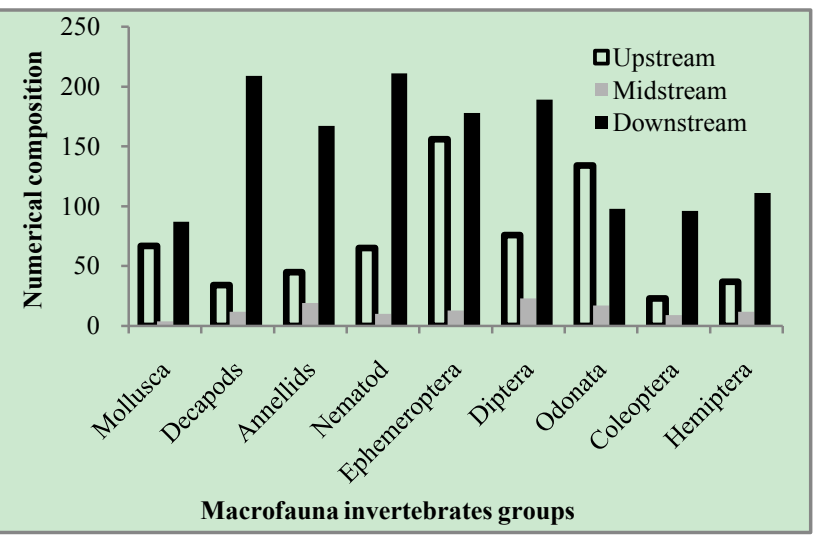

Figure 2. Spatial changes in the numerical composition of the dominant macro-fauna invertebrates

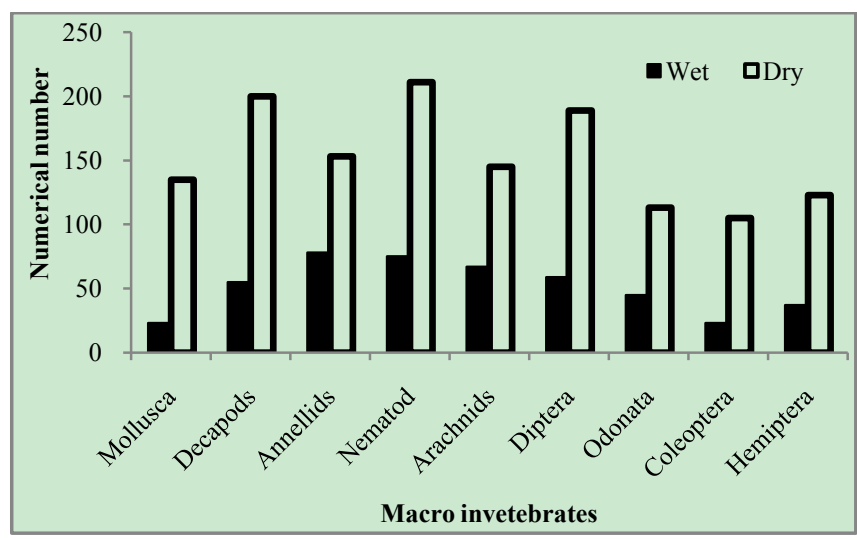

Figure 3. Seasonal changes in the numerical abundance of macro-fauna invetebrates 


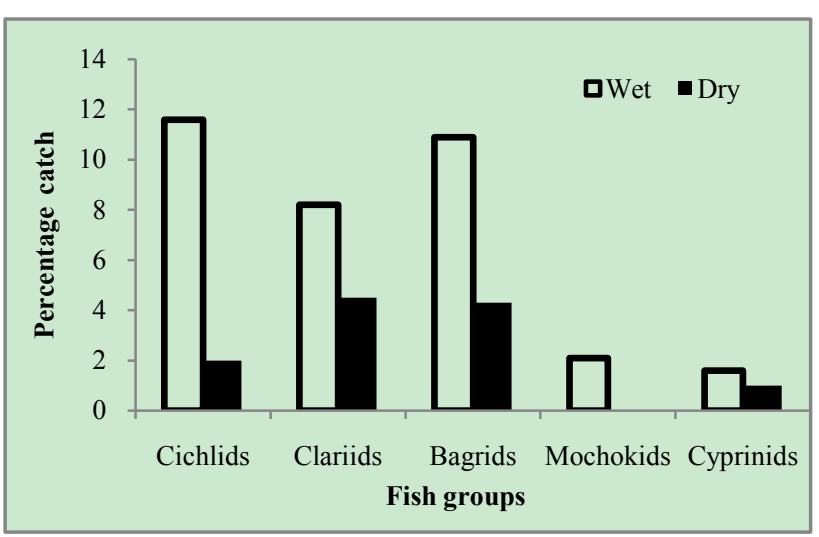

Figure 4. Seasonal changes in the percentage fish catch

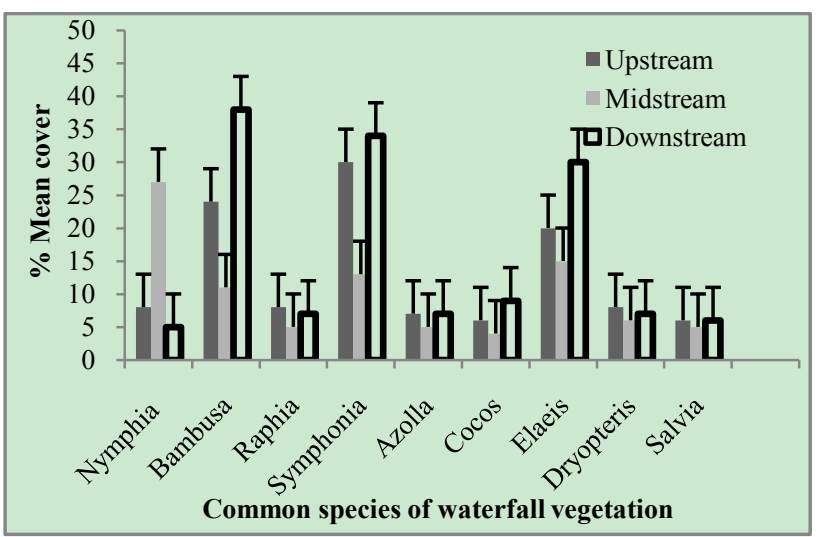

Figure 5. Percentage cover of the most common vegetation types in the three reaches of Agbokum water falls

\subsection{Fish Fauna}

A total of 548 fish representing 13 species from 5 families were sampled during the dry and wet seasons, with only one family being restricted to the wet season, which was of very rare taxa (Figure 4). The number of taxa, and relative proportion of each species present, upstream, midstream and downstream reaches are shown in Table 2. Cichlidae, Clariidae and Cyprinidae were the most abundant families accounting for $56.7 \%$ of the total catch. Tilapia zillii, Clarias gariepinus and Labeo coubie dominated overall catch constituting $45.5 \%$. Among the three dominant species, two benthic fishes (L. coubie and C. gariepinus) showed inverse distributional patterns. Clariid fish (C. gariepinus) was most abundant downstream and least represented, upstream. Cyprinid (L.coubie), on the other hand, dominated the upstream reaches and scarce downstream. Five species were site specific because of the association with the midstream portion of the river (L. senegalensis) and downstream reaches (A. occidentalis, H. longifilis, H. fasciatus and C. nigrodigitatus). Distribution of other species revealed no distinct trends.

\subsection{Vegetation}

The dominant vegetation at the bank are of freshwater swamp type; Azolla africana, Nymphia lotus, Commelina sp, Bambusa vulgaris, Dryopteris sp. and Salvia nymphellula. The fringing trees are principally Raphia vinifera, Symphonia sp., Elaeis guinneesis, Havea brasiliensis, Bambusasp,
Grewiasp and Cocos nucifera. The vegetation showed a distinct pattern in respect of percentage cover of species present. Total numbers of species varied significantly between reaches, but all reaches displayed similar change. Bambusasp, Symphonia and Elaeis guineesis displayed progressive increase from upstream reaching a maximum of 38.5 mean percent cover over the other species in the relatively undisturbed downstream. In contrast, the population in the highly disturbed midstream showed much smaller percentage cover values (Figure 5).

Table 2. Relative proportions of fish species for the three reaches (January 2006 to December, 2007)

\begin{tabular}{|c|c|c|c|}
\hline Reaches Up & rive Mid & $\begin{array}{c}\text { river } \\
\text { Down }\end{array}$ & river \\
\hline Family/species & $\mathrm{p}_{\mathrm{i}}$ & $\mathrm{p}_{\mathrm{i}}$ & $\mathrm{p}_{\mathrm{i}}$ \\
\hline Cichlidae & & & \\
\hline Oreochromisniloticus & 0.042 & 0.038 & 0.004 \\
\hline Tilapia zilli & 0.1100 .238 & 0.098 & Tilapiazilli \\
\hline Hemichromisfasciatus & 0.000 & 0.000 & 0.011 \\
\hline Pelmatochromis guntheri & 0.010 & 0.006 & 0.024 \\
\hline Clariidae: & & & \\
\hline Clariasanguil laris & 0.031 & 0.005 & 0.057 \\
\hline Clariasgariepinus & 0.023 & 0.014 & 0.315 \\
\hline Heterobranchus longifilis & 0.000 & 0.000 & 0.111 \\
\hline Bagridae: & & & \\
\hline Chrysichthys nigrodigitatus & 0.000 & 0.000 & 0.013 \\
\hline Auchenogla nisoccidentalis & 0.000 & 0.000 & 0.003 \\
\hline Mochokidae: & & & \\
\hline Synodontis clarias & 0.015 & 0.004 & 0.018 \\
\hline Cyprinidae: & & & \\
\hline Labeo coubie & 0.388 & 0.121 & 0.003 \\
\hline Labeo senegalensis & 0.000 & 0.044 & 0.000 \\
\hline Barbus occidentalis & 0.034 & 0.003 & 0.001 \\
\hline
\end{tabular}

\subsection{Richness and Diversity Indices}

Changes in the plankton, flora and fauna community assemblages of the Agbokum waterfalls ecosystems were reflected in species richness and diversity. The Shannon-Weiner diversity index for the biodata investigated showed significant difference between reaches, with downstream reaches having highest values while midstream were least (Table 3). Seasonal differentiation in the diversity indices and species richness revealed higher values for the wet season samples of plankton, fish and vegetation than dry. On the other hand, dry season invertebrate samples showed higher richness index and diversity values. Throughout the year, samples from the waterfalls region of the stream (midstream) exhibited very lowest diversity and richness values.

\subsection{Physico-chemical Characteristics}

Water depth, water discharge, water velocity and dissolved oxygen vary significantly between reaches $(\mathrm{p}>0.05)$ (Table 4). All biological species studied correlated negatively with water discharge and water velocity except the Cyprinids (Table 5). On the other hand, all the species correlated positively with dissolved oxygen apart from annelids and the marginal vegetation. 
Table 3. Diversity of macro and micro fauna and flora of Agbokum waterfalls during dry (D) and wet (W) seasons in the three sampling sites. $r=$ richness index, $d=$ Shannon weaner diversity index

\begin{tabular}{|c|c|c|c|c|c|c|c|}
\hline \multirow{2}{*}{ Reaches Seasons Items } & \multirow{2}{*}{ Diversity indices } & \multicolumn{2}{|c|}{ Upstream } & \multicolumn{2}{|c|}{ Midstream } & \multicolumn{2}{c|}{ Downstream } \\
\cline { 3 - 8 } & & $\mathrm{D}$ & $\mathrm{W}$ & $\mathrm{D}$ & $\mathrm{W}$ & $\mathrm{D}$ & $\mathrm{W}$ \\
\hline \multirow{2}{*}{ Phytoplankton } & $\mathrm{r}$ & 52 & 12 & 12 & 9 & 153 & 17 \\
\cline { 2 - 8 } & $\mathrm{d}$ & 0.55 & 0.28 & 0.03 & 0.03 & 0.69 & 0.28 \\
\hline \multirow{2}{*}{ Zooplankton } & $\mathrm{r}$ & 29 & 16 & 7 & 12 & 79 & 49 \\
\cline { 2 - 8 } & $\mathrm{d}$ & 0.12 & 0.28 & 0.16 & 0.05 & 0.63 & 0.16 \\
\hline \multirow{2}{*}{ Macro-invertebrates } & $\mathrm{r}$ & 33 & 12 & 18 & 10 & 89 & 45 \\
\cline { 2 - 8 } & $\mathrm{d}$ & 0.34 & 0.12 & 0.08 & 0.02 & 1.56 & 0.89 \\
\hline \multirow{2}{*}{ Fish species } & $\mathrm{r}$ & 14 & 28 & 7 & 7 & 11 & 38 \\
\cline { 2 - 8 } & $\mathrm{d}$ & 0.23 & 0.42 & 0.02 & 0.06 & 0.34 & 1.76 \\
\hline \multirow{2}{*}{ Vegetation } & $\mathrm{r}$ & 26 & 49 & 8 & 12 & 45 & 78 \\
\cline { 2 - 8 } & $\mathrm{d}$ & 0.12 & 0.42 & 0.02 & 0.04 & 0.54 & 1.55 \\
\hline
\end{tabular}

Table 4. Mean variation and F-values of the analysis of variance (ANOVA) of physico-chemical parameters of water measured at three sampling sites. I: Upriver, II: Mid-river, III: Downriver

\begin{tabular}{|c|c|c|c|c|c|}
\hline Properties & Upriver & Midriver & Downriver & Properties & F-value ANOVA \\
\hline Physical Conductivity $\left(\mathrm{uScm}^{-1}\right)$ & $36.6 \pm 11.0$ & $38.1 \pm 11.5$ & $25.3-58.2$ & 0.77 & $\mathrm{p}>0.05$ \\
\hline Water temperature $\left({ }^{\circ} \mathrm{C}\right)$ & $28.0 \pm 1.1$ & $26.6 \pm 1.2$ & $27.2 \pm 0.8$ & 3.36 & $\mathrm{P}>0.05$ \\
\hline Water depth $(\mathrm{m})$ & $1.4 \pm 0.7$ & $2.2 \pm 0.5$ & $4.8 \pm 0.6$ & 4.32 & $\mathrm{P}<0.05$ \\
\hline Water discharge $\left(\mathrm{m}^{3} \mathrm{~s}^{-1}\right)$ & $156.71 \pm 12$ & $1496.46 \pm 82$ & $189.8 \pm 13$ & 5.8 & $\mathrm{p}<0.05$ \\
\hline Water velocity $(\mathrm{m} / \mathrm{s})$ & $1.94 \pm 0.25$ & $1.01 \pm 0.3$ & $0.5 \pm 0.14$ & 4.32 & $\mathrm{p}<0.05$ \\
\hline Transparency $(\mathrm{cm})$ & $26.6 \pm 13.9$ & $29.5 \pm 14$ & $28.8 \pm 13.4$ & 1.56 & $\mathrm{p}>0.05$ \\
\hline Physical Conductivity $\left(\mathrm{uScm}{ }^{-1}\right)$ & $36.6 \pm 11.0$ & $38.1 \pm 11.5$ & $25.3-58.2$ & 0.77 & $\mathrm{p}>0.05$ \\
\hline Water temperature $\left({ }^{\circ} \mathrm{C}\right)$ & $28.0 \pm 1.1$ & $26.6 \pm 1.2$ & $27.2 \pm 0.8$ & 3.36 & $\mathrm{P}>0.05$ \\
\hline Chemical & & & & & \\
\hline Dissolved oxygen $(\mathrm{mg} / \mathrm{l})$ & $6.6 \pm 0.3$ & $9.61 \pm 0.2$ & $4.34 \pm 0.5$ & 3.98 & \\
\hline $\mathrm{pH}$ & $7.0 \pm 0.2$ & $7.0 \pm 0.2$ & $7.1 \pm 0.2$ & 1.43 & $\mathrm{P}<0.05$ \\
\hline
\end{tabular}

Table 5. Results of Pearson correlation analysis using physico-chemcal and biological parameters from Agbokum waterfalls

\begin{tabular}{|c|c|c|c|c|}
\hline Item & $\begin{array}{c}\text { Water } \\
\text { depth }\end{array}$ & $\begin{array}{c}\text { Water } \\
\text { discharge }\end{array}$ & $\begin{array}{c}\text { Water } \\
\text { velocity }\end{array}$ & $\begin{array}{c}\text { Dissolved } \\
\mathrm{O}_{2}\end{array}$ \\
\hline Chlorophytes & -0.675 & -0.564 & -0.654 & 0.654 \\
\hline Cyanophyceae & -0.766 & -0.843 & -0.321 & 0.435 \\
\hline Rotifers & -0.492 & -0.477 & -0.765 & 0.755 \\
\hline Cladocerans & -0.566 & -0.777 & -0.465 & 0.665 \\
\hline Cichlids & 0.586 & -0.345 & -0.234 & 0.788 \\
\hline Cichlids & 0.897 & -0.657 & -0.654 & 0.234 \\
\hline Cyprinids & 0.675 & 0.768 & 0.876 & 0.888 \\
\hline Decapods & 0.456 & -0.543 & -0.287 & 0.654 \\
\hline Annelids & 0.654 & -0.254 & -0.432 & -0.765 \\
\hline Azolla & -0.564 & -0.671 & -0.654 & -0.234 \\
\hline Nympha & -0.444 & -0.876 & -0.324 & 0.564 \\
\hline Commelina & 0.398 & -0.432 & -0.487 & -0.675 \\
\hline
\end{tabular}

\section{Discussion}

\subsection{Phytoplankton}

The phytoplankton composition in this study agreed with results of other workers[32,33] that blue-green algae and green algae dominate most tropical African waters. The dominance of Chlorophyceae in respect of species number and population density in this study had also been observed elsewhere[34-37] and the overwhelming presence in the dry season, attributed to the presence of bright sunshine and extensive catchment area, draining calcium rich agriculture land[38-41]. Physiological and behavioural flexibility of Chlorophyceae can accommodate environmental stresses better than most fast growing species[42]. Second in prominence was Cyanophyceae, which had also been found to be prominent in Bulgaria[43], Hungary[44] and Sanabria Lake (Spain)[45]. Cyanophyta dominance, and sometimes bloom are amongst the most visible symptoms of pollution[46]. The observation in the waterfalls is similar to findings[47] that the abundance of phytoplankton increases with increase in transparency, which normally associated with black flood (dry season), while the high turbidity associated with the white flood (wet season) results in a decrease in its abundance. It was also reported, during monsoon, mostly in ponds and reservoirs in Asia, where phytoplankton minimum can be observed during the wet months[48]. According to reports[49], most of the reservoirs in India have three plankton pulses coinciding with the post-monsoon (October to November), winter (December to February) and summer (March to May) seasons, all within the dry season. During the wet months (June-August) flushing disturbs the standing crop of plankton. However, when the destabilising effects wean away, the nutrient input favours an accelerated plankton growth in November. The annual black and white flood pattern of water bodies is the most important factor regulating phytoplankton production[50,51]. Phytoplankton abundance, vary with flood condition. The high temperature, bright sunlight and rapid tropholytic activities by the decrease in water level and the movement of the deep, nutrient-rich areas into the fold of tropholytic zone, increase plankton biomass during dry month of November and April. The waterfalls region of the study area recorded least density of phytoplankton due to high level of disturbance caused by the impact of high water discharge on the environment. 
Re-suspension of particles often observed in this region leads to high water turbidity and therefore low light penetration, low degree of algal sedimentation, and therefore reduced phytoplankton production. Benthic algal production is also hampered by the turbulence effect of water in this region constantly bringing to the top all materials at the bottom[52]. Planktons were moved swiftly from upstream with high flow velocity and water turbulence to downstream with stable ecology, resulting in higher plankton diversity and abundance downstream.

\subsection{Zooplankton}

The zooplankton population dominated by copepods and cladocerans had also been documented[53]. There may be alternation in abundance between crustaceans and rotifers as reflected in the distribution and abundance of zooplankton in the sampled parts of the river and seasons. These alternation in the abundance of species in water body was regarded as a booster of all year round food for fish in the lake[54].The zooplankton forms respond similarly to disturbance in water environment as phytoplankton. Low densities of all zooplankton species observed in the middle reaches (waterfalls) could be due to high water discharge. Discharge rate is important both directly or indirectly, as it influence the environment by creating turbulence and high turbidity in this region[55]. Suspended particles have been found to hinder metabolism in copepods[56] and turbulence prevent larval forms from settling and developing to adult stages and hence die shortly before metamorphosis[57].

This study showed that the seasonal variation in zooplankton concentration could largely be due to the rotifers which normally constitute major diet items of larger zooplankton during the dry season. Species of rotifers and crustaceans considered good indicators of the trophic state of the water bodies were identified in the zooplankton community. Dominant rotifers species of Filinia longiseta, Bracchionus quadridentatus and Synchaeta oblonga and crustacean zooplankton community populated mainly by copepods and cladocerans, as a result of increase in cyclopoid copepodids and mesocyclops, are indicative of good water quality[58]. Temperature and the availability of food are about the most important factors controlling the abundance of zooplankton in water[59]. In this study, with higher temperature regimes during the dry season coupled with high level of food in the water as a result of high primary productivity (phytoplankton), can be responsible for the high populations of zooplankton. In the dry season the zooplankton population appeared to have great stability and in the rainy season the population is suspected to lack stability. This may depend on the residence time of water and on the abrupt water change which occur frequently during the rainy season[60]. The increased turbidity of the flood (wet season) destroys the periphytic algae and causes a decline in the amount of phytoplankton[61,62] which in turn reduces the standing crop of the herbivorous zooplankton fish food[63]. Zooplankton is restricted to aerate upper water layers and littoral regions of the water during dry season[64, $65]$.

\subsection{Macro-Invertebrates}

The gradual decrease of current velocity was evident from upstream to the middle reaches, then decrease abruptly to the downstream reaches where the velocity was least during the period of study. According to findings[66], flow velocity influences the type of river bed, amount of silt deposition, which in turn affects macro-invertebrate abundance. The significant differences in population densities of macrofaunal species between reaches of the waterfalls may therefore be due, in part, to differences in composition of the substratum which was muddy and silt downstream with sandy and rocky upstream and midstream reaches. The larval forms of most deposit-feeding macro-benthic fauna require fine sediments in which to burrow. The greater quantity of organic matter present in downstream reaches[67], is probably instrumental to decreasing the compartment of the sediments, thereby facilitating the burrowing of larval forms of decapods and polychaetes which formed dominant macro-fauna downstream. Another reason for higher density of macro-invertebrates downstream could be due to large surface area of the reaches which expose the site to air and sunlight as well as abundance of organic debris which favor the photosynthetic activity of aquatic plants[68]. The macro-invertebrate assemblages downstream, is striking in the fact that the decapods crustaceans dominated and were present in high numbers. Research findings had earlier implicated the presence of decapods to relatively unpolluted segment of the river since they are not tolerant of polluted water[69]. On the other hand upstream reaches where the velocity was rather high, the macro-invertebrate community was dominated by Odonata and Ephemeroptera (Baetissp) which according to findings[70,62], may be high flow adopted invertebrates. Midstream reaches had consistently lower density of invertebrates than other reaches due to higher water discharge rate which permanently suspended particles in water and in turn reduced to minimum invertebrate density in the region. The higher density of macroinvertebrates during the dry season could be as a result of the unstable nature of the substrate during the wet season arising from inputs of storm water[63-65].

\subsection{Fish Species}

Seasonal differentiation evident in higher number of species and individuals caught during wet months of the study period, agree with other results which described larger ichthyofaunal densities in water bodies in Grahamstown in the rainy season[66-68]. Reasons for the variation were ascribed to the connection of the water bodies to the sea which allows free movement of species across the two habitats during flood and these species being able to recruit during flood condition. Agbokim Waterfalls being drained by two small rivers, Ekue and Bakue, which are tributaries of the Cross River system with linkage to Cross River estuary from the 
lower reaches, could have exhibited the same variation. Also because of the considerable seasonal differences in dissolved oxygen concentration in the system, both at low water and during the floods, this factor appears to have played an essential role in determining the distribution of fish within the system. In general the more active the species the more it tends to avoid de-oxygenated areas[69]. Most species encountered downstream during dry season have adaptation for survival in low dissolved oxygen conditions like presence of external gills (Clarias, Heterobranchus). These species form a group that is well adapted to swamps life and tend to concentrate in the more de-oxygenated small pools and swamps of the floodplain during low water, when other more active species like Tilapia and carp are to be found in the midstream (water fall) and upstream respectively.

Although on a community basis the three reaches did not separate out, some species when analysed individually revealed specific range preferences. Two heterologous species between two genera, C. gariepinus and L. coubie, the two most common and economically viable benthic fishes found in this study, demonstrated opposite habitat preference, with C. gariepinus dominating the lower reach and $L$. coubie more abundant in the upper reach. This opposing habitat preference and the attendant ecological and trophic heterogeneity reduce competition, and may be responsible for the overwhelming success of the two species in the Agbokum waterfalls. The relatively higher number of $C$. gariepinus in the lower reach during this study may be due to the fact that being mud-dwelling species, most individuals found their natural habitat downstream. The common carp, L. coubie adapted to live in shallow rocky bottom, assemble in the rocky upstream. Another dominant freshwater species ( $\mathrm{T}$. zilli) demonstrated great preference to the turbulent well aerated midstream reaches. This distributional trend, in a similar study[70] was attributed to several factors including fast water current, suitable breeding area, marginal vegetation and the absence of competitors and piscivorous predators.

\subsection{Vegetation}

Quantitative difference in numerical abundance of vegetation types between reaches, in this study, implies variation in control on a very local scale[71]. In the present study, experimental field study had been used to assess the impact of waterfall disturbance on marginal vegetation population in the different reaches of the waterfalls. The assessment of the plant size was difficult because individuals vary greatly in the proportion of their stem. Although there was general deterioration in the numerical abundance in the middle reaches of the waterfalls, Azolla africana, and probably Nymphia lotus and Commelina sp were endemic forming permanent marginal vegetation along all stretches of the midstream. The distribution pattern and composition of the vegetation change in a non-random way during the study period with Raphia vinifera, Havea brasiliensis, Grewia sp and Cocos nucifera shrinking in size from $34 \%$ to $8 \%$ at the midstream stretches of the river while the nymphia- rich vegetation becomes more frequent than expected. Nymphia has become a biological invader and has exhibited a full range of impact and abundance in this disturbed midstream reaches.

\subsection{Diversity}

Shannon Weaner diversity function for samples of phytoplankton, zooplankton and macro-invertebrates studied, reveal that dry season samples of these species were more diversified and stable. On the other hand fish and vegetation appear to be more stable during the wet season considering the higher richness and diversity during this period. However, communities in the waterfall region (midstream) of the river may be unstable throughout the year as reflected in their low values of richness and diversity during both seasons. If the integrity of such waterfalls in the tropics are protected, they will support growth and survival of organisms, throughout the year.

\subsection{Physico-chemical Properties}

The distribution and abundance of macro-invertebrates, as the results show, were probably affected by the physico-chemistry of the waterfalls, such as dissolved oxygen, water velocity, water discharge and water depth. Pearson's correlation analysis showed that some of these parameters correlated significantly with some species of Chlorophytes, Cyanophyceae, rotifers, cladocerans, cichlids, clariids, cyprinids, decapods, annelids, azolla, Nympha and Commelina. The high correlation that occurred between these groups of organisms and physico-chemical properties of the water suggest that the physic-chemical parameters influenced the distribution and abundance of organisms as already reported[71,72].

\section{Conclusions}

Waterfalls can also be important for fisheries and biodiversity conservation, as rich biome for indigenous and exotic species which are swept upstream and over the waterfalls, settle downstream in a more stable environment. The waterfalls reaches are not completely lifeless as assumed by many researchers in Africa, but harbor some turbulent tolerant macro-biota. Among the plankton community, waterfalls contributed significant percentage of Trachelomonas sp., Scenedesmus denticulatus, Chlorella ellipsoidea and Nostoc lobatus. Labeo coubie and Tilapia zilli were the fish species that were most abundant in the waterfall region. Nymphia vegetation has become a biological invader and has exhibited a full range of impact and abundance in this disturbed midstream reaches. The disturbance regimes of the midstream reaches of Agbokum waterfalls combined with its very low faunal and floral diversity has made the environment unstable therefore susceptible to the invasion of disturbance tolerant biota. 


\section{ACKNOWLEDGEMENTS}

The authors wish to thank the Management of Cross River University of Technology for the financial support and the use of the laboratory facilities. We also thank the Vice Chancellor Prof. Enebong E. Enebong and management of the University for the encouragement.

\section{REFERENCES}

[1] Chernicoff S, Fox H, Venkatakrishnan R, 1997. Essentials of Geology. Worth Publishers, New York, 1997

[2] Fischer G, Harris M. Waterfalls of Ontario.Waterfallogy 101. Ontario, 2003

[3] Chester T, Strong J, Ayers P. SGM: The Waterfalls. NewYork, 1999

[4] Adebisi AA. The physico-chemical hydrology of tropical seasonal river-Upper OgunRiver,Hydrobiologia 79:157-168

[5] Ayodele IA, Ajani EK. Essentials of fish farming (aquaculture).Odufuwapublishers, Ibadan, 1988

[6] Tokeshi M, Schmid PE. Niche division and abundance: an evolutionary perspective. Pop. Ecology 2002; 44: 189-200

[7] Brown JH. On the relationship between abundance and distribution of species. Am Nat 1984. 124: 225-279

[8] Schlosser IJ. A conceptual framework for fish communities in small warmwater streams. In community and evolutionary ecology of North American stream fishes.In: Mathews, WJ Heins DC. (Ed), University of Oklahoma Press, Norman, Oklahoma, 1987

[9] Teugels GG, Reid M, King RP. Fishes of the Cross River Basin. Taxonomy, Zoogeography, ecology and conservation. Ann. Mus. R. Afr. Centr. 1992; 266: 1-32

[10] Offem BO, Akegbejo- Samsons Y, Omoniyi IT, Ikpi GU. Dynamics of the limnological features and diversity of zooplankton populations of the Cross River System SE Nigeria, Knowl. Managt. Aquat Ecosys. 2008; 393: 2-19

[11] Ajani EK. Effects of biotic and abiotic components of the habitat on fish productivity in Lagos Lagoon, Nigeria. Ph.D Thesis University of Ibadan, 2001

[12] UNESCO. Phytoplankton Mannual.UNESCO. Paris. 1978

[13] Prescott GW. Algae of the West Great Lakes Area, W.M.C. Brown Company Publishers, Dubugue Press, Towa, 1970

[14] Edmonton WT. Freshwater biology. In: John W. Ed., New York, 1957

[15] Sharma OP. Text book of algae. TATA McGrawhill New Delhi. 1986

[16] Durand JR, Leveque C. Flora et Fauna aquatiques de L. Afrique,SaleloSoundanienne Tomes I and ORSTROM, 1980

[17] Jeje CY, Fernando CH. 1985.A practical guide to the identification of Nigerian ooplankton, 1985
[18] Lenat DR, Penrose DL, Eaglesor AW. Variable effects of sediment addition on stream benthos, Hydrobiologia 1981; 79: 187-197

[19] Kellog LL. Save our streams. Monitor's guide to aquatic macroinvertebrates. Izaac alton League of America Gaithersburg Maryland 1994

[20] APHA. American Public Health Association: Standard methods for the examination of water and waste water Washington DC, 1997

[21] Hawking JH. A prelimnary guide to keys and zoological information to identify invertebrates from Australian inland waters, In: Darling M. Ed., Freshwater Research Australia, 2000

[22] Therschinger G. 2001. Prelimnary keys to the identification of larva of the Australian synthemisticidae, In: Darling M. Ed. Freshwater Researcch. Australia,2001

[23] Elvira M. Taxonomic revision of the Genus Chondrostoma Agassi 1835 (Pisces: Cyprinidae) Cybium 1987; 11: 111198

[24] Erk'akan F, Nalbant TT, Ozeren SC. Seven new species of Barbatula three new pecies of Schistura and a new species of Seminemacheilus(Ortariophysi:Balitoridae: emachellinae) from Turkey. J. Fish. Intl., 2007; 2:69-85

[25] Teugels GG. Prelimnary results of morphological study of five African species of the subgenus Clarias( Pisces: Clariidae) J Nat Hist, 1982; 16: 439- 553

[26] Fischer W, Schneider M, Bauchot ML. MediterraneeetMer Noire Zone De Peche 37 Revision Volumn II Vertebrates FAO Rome. 1987

[27] Clarke KR, Warwick RM. Change in Marine communities: An Approach to Statistical analysis and interpretation. Natural Environmental Reseach Council,Bournemouth, 1994

[28] Krebs CJ. Ecology: The experimental analysis of distribution and abundance. Harper intellectual edition, New York 1978

[29] Zar JH. Biostatistical Analysis. Pretice- Hall International, London. 1996

[30] Vyverman W. The Indo-Malaysian North-Australian phycogeographical region revised. Hydrobiologia, 1996; 118:107120

[31] Lewis WM. Tropical lakes, How attitude makes a difference. In: (Schiemer F, Boland KT eds.) Perspective in Tropical Limnology. SPB Academic Publishing, 1996

[32] Tressler WL, Tiffany LH, Spencer WP. Limnological studies of Buckeye Lake Ohio J. Sci.. 1940; 40: 261-266

[33] Willen T. The phytoplankton Gordon, A bay of Lake Maleren, OIKOS, 1959; 10: 241-274

[34] Silva EIL. Phytoplankton Characteristics, Trophic Evolution and Nutrient Dynamics inan Urban Eutrophic Lake: Kandy Lake in Sri Lanka. In: Reddy MV Ed, Restoration and Management of Tropical Eutrophic Lakes. Oxford and IBH Publishing, New Delhi, 2005

[35] Adeniji HA. Seasonal variation in the pelagic primary productivity of the Kainji Lake and the River Niger below the Dam, Kainji Lake Annual report, 1975a; 79: 23-34 
[36] Stoyneva MP. Steady-state phytoplankton assemblage in shallow Bulgarian wetlands. Hydrobiologia, 2003; 502: $169-177$

[37] Padisak J, Reynolds CS. Selection of phytoplankton associations in Lake Balaton, Hungary in response to eutrophication and restoration measures, with special reference to the Cyanoprokaryotes. Hydrobiologia, 1998; 384: 46-56

[38] Hoyos C, Comin FA. The importance of inter-annual variability for management. Hydrobiologia, 1999; 395/396: 281291

[39] Adeniyi HA. Preliminary studies of fisheries limnology of Bakolori Lake, Nigeria. Report presented to Sokoto Rima River Basin Development Authority, 1978

[40] Adeniji H.A. Limnology and biological production in the pelagic zone of Jebba Lake, Nigeria. PhD Thesis, Univ. of Ibadan. 1979a

[41] Ewa-Oboho IO. 1999. Seasonal variation and community structure of epibenthic algae on the roots of mangrove Rhizophora mangle at a shallow tropical estuary, Tropical ecology, 1999; 34(2): 160-167

[42] Ewa-Oboho IO, Oladimeji S. Benthic - pelagic production in the mouth Cross River Estuary. Tropical Journal of Applied Ecology, 2004; 41: 162-176

[43] Egborge AB. Biodiversity and chemistry of Warri River. Ben Miller. Warri, Nigeria 1981b

[44] Nelson SM, Lieberman DM. The influence of flow and other environmental factors on benthic invertebrates in the Sacramento River, USA.Hydrobiologia, 2002; 489: 117-120

[45] Edung S. Dynamics in the epibenthic larvae in relation to minor petroleum spill in the Cross River Estuary, M.Sc. Thesis Universty of Calabar, Nigeria, 2001

[46] Sendacz S, Kubo E, Cestarolli MA, 1985. Limnologia de reservatios do estado do Sao Paulo, Brasil. VIII zooplankton, $1985 ; 145-176$

[47] Imoobe TOT, Adeyinka TO. Crustaceans of Jamieson River, Nigeria. Ph.D Thesis of the University of Benin, Benin, Nigeria, 2010

[48] Schoener TW. Ecologicalinteractions.In: In: Myer RR, Giller PS Ed. Chapman and Hall, London, 1988

[49] Pennack RW. 1949. The dynamics of fresh-water populations. Ecological Monograph, 1949; 16: 342- 366

[50] Bidwell A. The effect of water level fluctuation on the biology of Lake Kainji, Nigeria. The Nigerian field, 1976; 41 (4): $156-165$

[51] Bidwell A. Observation on the biology of the nymphs of Povilla adusta (Ephemeroptera) in Lake Kainji. Hydrobiologia, 1976; 67 (2): 1022-1085

[52] Turner JL. The fish population of impounded Kainji Lake, FAO Technical Report. 1970; 1: 1-59

[53] Ikpi GU, Offem BO. Fish fauna of Agbokum waterfalls in South- eastern Nigeria, J. Asian Sci. Res., 2011; 1(6): 299-307

[54] Ogbeibu AE, Oribhabor BJ. Ecological impact of River impoundment, using macro- invertebrates as indicators, Water research, 2002, 36: 2427-2434

[55] Rader RB, Ward JB. Influence on regulation of environmental condition and the macroinvertebrate communities in the Upper Colorado River, Regulated Rivers Research and Management, 1988; 2:597-599

[56] Charpenter B, Morin A. Effect of current velocity on the ingestion rate of blackfly, Canadian J. Fish. Aquat. Sci.,1994; 51: 1615-1618.

[57] Victor R, Ogbeibu AE. Macro-invertebrates communities in the erosional biotope of an urban stream in Nigeria, 1991; Trop. Zool. 4: 1-12

[58] Edokpayi CA, Okenyi JC, Ogbeigu AE, Osemen EC. The effects of human activities on the macrobenthic invertebrates of Ibekuma stream, Ekpoma, Nigeria. Biosci. Res. 2000; 12 (1) $79-83$

[59] Cowley PD, Whitefield AK. Ichthyofaunal characteristics of a typical temporarily open/closed estuary in the south-east coast of South Africa. Ichthyology, 2001; 71:1-19

[60] Vorwerk PD, Whitefield AK, Cowley PD, Paterson AW. A survey of Eastern Cape estuaries with particular reference to the ichthyofuana, 2001; Ichthyology 72: 1-18

[61] Harrison TD, Whitefield AK. Fish community structure in three temporarily open/closed estuaries of the Natal coast, Ichthyology, 1995; 64:1-58

[62] Welcome RL. River fisheries in Africa. The relationship to flow regimes. NAGA, 2003; 26: 23- 25

[63] Whitfield AK, Blaber SJM. The distribution of freshwater cichlids Sarotherodo massambicus in estuarine systems. Env. Biol, 1979; Fish 4: 77- 81

[64] Faroque S. Riverine angiosperm of West Africa, J. Trop. Ecol. 1989; 32:167-171

[65] Barnett BE. Oligochaetes as indicators of pollution in the Humber with special reference to Turbicoides, International J. Environ.,1983; 34: 12-45

[66] Oke OO. Limnology and macrobenthos of Owena reservoir, PhD Thesis, University of Ibadan, Ibadan, Nigeria, 1990

[67] Karlman SG. The annual flood regime as a regulatory mechanism for phytoplankto production in Kainji Lake, Nigeria. Hydrobiologia, 1982; 86: 93-98

[68] Krinitskii L. Protected Areas in the worlds industrially advanced regions: importance, progress and problems. Second World Conference on National Parks, 1972. Amsterdam

[69] Sugunan VV. Ecology and fishery management of reservoirs in India. Hydrobiologia, 2000 430: 121-147

[70] Tumwesigwe C, Yusuf SK, Makanga B. tructure and composition of macro-invertebrates of a tropical forest stream, Western Uganda African J. Ecol. 2000; 38 (1): 72-76

[71] Silva EIL. Ecology of phytoplankton in tropical waters: Introduction to the topic and ecosystem changes from Sri Lanka. Pollution, 2004; 4: 25-35

[72] Kurasawa H, Shiraishi Y. Studies on the biological production of Lake Suwa.Research Institute of Natural Resources, 1994 